\title{
Afghan Refugee Journeys: Onwards Migration Decision Making in Greece and Turkey
}

\begin{abstract}
This paper contributes to the lack of research on refugee journeys by examining the factors influencing Afghan refugees plans to stay in Greece or Turkey or migrate onwards as a continuation of their fragmented refugee journeys. Following from the seminal article of BenEzer and Zetter (2015) this paper examines the four conceptual challenges of refugee journeys of: temporal elements, drivers and destinations, the process of the journey and the wayfarers characteristics. Using a quantitative approach with a unique original dataset of 364 Afghans in Greece and Turkey, regression analysis is used to examine the decision making of Afghans to stay or migrate onwards within the context of the four conceptual challenges of refugee journeys. The results show that all the conceptual elements are significant in influencing Afghan decision making for the continuation of their refugee journeys. The paper further contextualizes these results and highlights policy implications.
\end{abstract}




\section{Introduction}

Over the past decade there has been an increasing number of Afghans migrating to Greece and Turkey as they seek access to the rest of Europe. The ongoing conflict in Afghanistan including the increasing insecurity from 2008 onwards, combined with the increasingly hostile environment for Afghan refugees in Iran and recent repatriations from Pakistan, has led to continued migration movements further afield in search of safety and security. Research has demonstrated the long and arduous journeys that Afghans face in their movements to Europe (Crawley et al., 2016; Dimitraidi, 2015; Donini et al., 2016; Kaytaz, 2016; Kuschminder and Siegel, 2016; Schuster, 2011; UNHCR, 20120). These journeys are generally fragmented with stops in first Turkey and then in Greece as countries of transit, which can last from days to months or years.

Along the trajectory of fragmented journeys to Europe Greece and Turkey play different roles with Turkey being the last departure point for Europe and Greece being the first country of entry into the European Union (EU). It is important to not assume, however, that all Afghan refugees in Greece and Turkey seek to continue their journey. This perception is commonly portrayed; however, both Greece and Turkey now have fairly established Afghan communities. It is unclear as to the temporariness or permanency of these communities and the intentions of the Afghans living within these countries for settlement versus feeling 'stuck' and unable to continue their journeys. The concept of the 'stuck refugee' has been applied in contexts such as Egypt (Jacobsen, Ayoub, and Johnson) and Indonesia (Missbach, 2015), among others. The stuck refugee is immobilized in the current country by the policies of destination states that work to prohibit their onwards migration (Missback, 2015). At present, the concept of the stuck refugee actively describes the thousands of refugees in Greece and Turkey that have been barred from continuing their journeys by the EU-Turkey deal and the closing of the Balkan route. At the time of research in 2015 , these current policy restrictions were not in place.

The purpose of this paper is to examine the factors that influence the decisions of Afghan refugees in Greece and Turkey to plan to continue their journeys through onwards migration or to stay in the current country. Within the Afghan context increasing research has characterized the reasons for flight of continual insecurity versus specific migration triggers (UNHCR, 2010; Vervliet et al., 2014). However, limited research has focused on refugee journeys with the journey itself as a unit of analysis (BenEzer and Zetter, 2015) and simultaneously there is dearth of literature on decision making in transit (Townsend and Oomen, 2015). In this paper, I examine the planned decision of Afghan refugees to stay or migrate onwards from Greece and Turkey. This is arguably a key decision within their overall refugee 
journey and thus represents a substantial part of the journey itself and a worthy area of further investigation.

BenEzer and Zetter (2015) argue that there are four conceptual challenges in understanding refugee journeys: the temporal aspect, drivers and destinations, the process of the journey, and the wayfarers characteristics (314). This paper examines the decision of Afghan refugees to stay versus migrate onwards from Turkey or Greece based on these four conceptual challenges identified by BenEzer and Zetter (2015). Furthermore, BenEzer and Zetter (2015) discuss the need to focus on methodologies that allow for a better understanding of the journey, for which they recommend narrative interviews. In this paper, I use a quantitative methodology not discussed by BenEzer and Zetter (2015). Although not generally considered for understanding journeys, surveys allow for gathering data with a larger population and regression analysis enables a contribution in understanding the relationship between how making a decision to continue a journey to another country or not is correlated with the conceptual aspects of the journey (the temporal aspect, drivers and destinations, the process of the journey, and the wayfarers' characteristics). This paper thus contributes to the literature by first addressing a significant gap of understanding Afghan refugee journeys, and second proposing and using quantitative methods to examine and enhance our understandings of refugee journeys.

This paper is based on data collected within the...removed for review purposes. A total of 1,056 surveys were completed with migrants and refugees from Afghanistan, Iran, Iraq, Pakistan and Syria from May-July 2015 in Athens and Istanbul. This paper focuses solely on the Afghan respondents included in this sample (Athens=166; Istanbul=198; total=364). Afghans are an important group to understand as emigration from Afghanistan increases and opportunities to receive international protection decreases for Afghans.

Within this paper, the term 'refugee' is purposely used and applied for the Afghan respondents. The refugee label has become highly politicized (Zetter, 2007) and in the context of the 2015 flows and EU 'migration crisis' there has been a political and media push to de-label refugees and focus on 'economic migrants' (Crawley and Skleparis, 2017), thus reducing the space of protection (Zetter, 2015). In the past, Afghans were widely regarded as having a prima facie claim to protection under international refugee law, but this has shifted over the past decade with policy changes in Europe wherein Afghans are no longer viewed as having a right to international protection in several EU member states (Crawley and Skleparis, 2017). Labels are not fixed and the current reality of many Afghans in Greece and Turkey, and newly arriving in other EU member states, is that they have at times 
in their lives been 'refugees', at other times been 'migrants', and at other times may have been both of these labels simultaneously or somewhere in between (Crawley and Skleparis, 2017). Due to the complexity of Afghan migrations and the political salience of the refugee label, in this paper I use the term Afghan refugees widely, recognizing that not all respondents may be refugees, some may be migrants, some may be in-between, some neither and some may be both migrants and refugees.

Following from this introduction this paper is organized into six following sections. First, a brief overview is provided on Afghans journeys to Europe and the second section examines the conditions for Afghans in Greece and Turkey. The third section presents the hypothesis statements guiding this paper and the forth presents the data and methods of the study. The final sections present the results, discussion and the conclusion.

\section{Afghans Journeys to Europe}

Afghanistan has a complex migration history that is characterized by back and forth movements from different locations for trade, employment, marriage, and security (Schuster and Majidi, 2013). Migration is an integral part of survival and livelihoods in Afghanistan. The long-standing conflict and difficult recovery has led to Afghanistan continuing to be one of the largest refugee producing regions in the world and asylum seeking groups in Europe. In 2015, Afghanistan was the second largest refugee source country at 2.7 million (UNHCR, 2016) and a total of 181,360 Afghans claimed asylum in the EU, an increase of more than 400 percent from $2014(41,405)$ (Eurostat, 2016). Despite the high level of flows and claims from Afghan asylum seekers in Europe, Afghans also experience failed asylum claims and high levels of deportations (Schuster and Majidi, 2013). In 2015, the protection rates of Afghans ranged from 5 percent in Bulgaria, to 53 percent in the Netherlands, to 92 and 95 percent respectively in Switzerland and Italy (AIDA, 2017). The acceptance rate in Greece was 60.5 percent in 2015 (AIDA, 2017). The destination within Europe has been highly important for Afghans in terms of protection rates.

In 2015, the largest host countries to Afghan refugees continued to be Iran and Pakistan, with the former hosting just under a million registered Afghan refugees and the later 1.5 million, with many more being unregistered (UNHCR, 2016). The situation for Afghans in both countries has become increasingly hostile, with Afghans now being repatriated from Pakistan. In Iran, regardless of legal status (there is an unknown number of unregistered Afghans in Iran) Afghans face several challenges. Afghans are only permitted to work in their areas of residence and are only authorized to work in specific jobs (Farzin and Jadali, 2013). In 2007, Iran declared several 'no-go areas' for Afghan refugees to limit their movement within the country (Farzin and Jadali, 2013). Afghans are often unable to access higher 
education and face discrimination, arbitrary detention, risk of deportation and severe restrictions on their residency and movement in Iran. The harshening conditions in Iran are a key reason Afghans are leaving the country, as was reflected by the respondents in this study. Furthermore, Pakistan has also engaged in large-scale forced repatriations of Afghans in 2016.

Afghans have been migrating for decades and often give different and plural reasons for their migration decisions. Increasing barriers to migration for Afghans have led to what Collyer (2010) terms fragmented migration movements. Fragmented movements are characterized by the "fragmented" nature of their migration, broken into a number of separate stages, involving varied motivations, legal statuses and living and employment conditions' (Collyer, 2010: 275). Afghans movements to Europe typically occur in these fragmented journeys (Dimitraidi, 2015; Donini et al., 2016; Kaytaz, 2016; Kuschminder and Siegel, 2016). Kaytaz (2016) highlights that these journeys often do not have a clear start or end, but that the journeys themselves can be transformational for the refugee. That is, experiences during the refugee journey including failed onwards migration experiences from intended transit countries can inform and change opportunities for the refugee.

For Afghans migrating to Europe, their journey typically occurs in three central stages. The first stage is the departure from Afghanistan, Pakistan or Iran and the journey to Turkey. Most commonly, this stage is made by foot and or vehicle, although sometimes it is done by air (Donini et al., 2016). This stage can be highly dangerous in itself as Afghan refugees have reported long journeys through difficult conditions with walking for days on end without food and water, exposure to the elements and cold, and abuse and extortion by smugglers, primarily along the mountain passes between Iran and Turkey (Kaytaz, 2016). In this study, respondents reported deaths from people falling off the steep mountain passes, dehydration and starvation, and from being captured and tortured in Iran. Crossing the border into Turkey tends to characterize the main event in this stage and then the ensuing arrival in a larger Turkish city, such as Izmir or Istanbul.

The second stage is the movement from Turkey to Greece. At present, this flow has largely subsided due to the EU-Turkey deal. In 2015, this journey most commonly occurred by sea in small plastic boats. In the past, this part of the journey also occurred by foot into Bulgaria or crossing the Evros river. The journey by sea from Turkey to Greece is considered the most dangerous part of the journey.

The third stage is generally the movement from Greece to the onwards destination, which may also involve several stages in itself. Prior to July/ August 2015, movement beyond Greece was very difficult. The three main routes taken to leave Greece were going north to the Republic of Macedonia, 
going by sea to Italy, or departing from an airport (Dimitriadi, 2015). The opening of the Balkans Route made onwards migration accessible from Greece in 2015, however, the route was closed again in 2016.

The journey to Europe for Afghans can been characterized as long, arduous, and dangerous. There are several risks along the way including drowning, exploitation or abuse, detention, and deportation. Often these journeys last up to a year or longer as refugees stop at different points to work to gain further money and plan the next stage of their journey. Decision making at these stopping points is influenced by a complex array of the overall migration ambition, familial expectations, structural conditions, and information and stories acquired by other refugees and friends at different stages of the journey (Donini et al., 2016). All these complex factors influence Afghans decision making at these critical points in their journey. This paper focuses on decision making at the second and third stage of the journey when Afghan refugees are in Turkey or Greece.

\section{Afghans in Turkey and Greece: Rights and Living Conditions}

Afghans have access to different sets of rights in Greece and Turkey. Turkey is a signatory to the 1951 Geneva Convention with a geographical limitation to only apply the Convention to people from Europe. In 2013, the Turkish Parliament adopted the country's first migration law, termed the Law on Foreigners and International Protection, which came into force in April 2014 (Kilberg, 2014). This law provides three statuses for humanitarian protection of: refugee (granted only to those coming from Europe); 'conditional refugee' (applied to cases of convention refugee outside of Europe); and a status of 'subsidiary protection' for those who do not qualify as a refugee or conditional refugee but would face death, torture, inhumane treatment or indiscriminate violence upon return. Since coming into force, the status of 'subsidiary protection' has been applied to Syrians in Turkey, meaning that Syrians can

immediately receive this status in Turkey without going through refugee status determination procedures (Ineli-Ciger, 2015). Other nationalities, including Afghans, must apply for 'conditional refugee' status in Turkey. Migrants that do receive either subsidiary protection or conditional refugee status cannot necessarily acquire naturalization over the long-term in Turkey, meaning that protection is always temporary (Ineli-Ciger, 2015).

When applying for 'conditional protection' Afghans are placed into a dispersion programme and assigned to a 'satellite city'. In these satellite cities they must report every two weeks or every month to the police to be re-confirmed/ registered. They are not legally allowed to work and also need to pay for their own living expenses. Many Afghan respondents in this study leave the satellite cities to live in 
larger centers such as Istanbul and travel back to the satellite city for their regular processing. Leghtas and Sullivan (2017) have highlighted several deficiencies in protection for conditional refugees such as: the requirement to live in satellite cities, access to information and the asylum system, no housing assistance, no access to work permits and legal livelihood opportunities, and insufficient assistance in health care.

The UNHCR is also active in Turkey, however, in 2013, the UNHCR stopped processing claims from Afghan refugees due to capacity issues. The UNHCR still registers Afghans, which gives them protection from being deported or detained, but does not give them the option to be considered for resettlement (Dimitraidi, 2015). As of 31 December 2015, there were 2.5 million people of concern to UNHCR in Turkey and in 2015 there were only 7,577 resettlement departures from Turkey (UNHCR, 2017; UNHCR, 2017b), which is clearly grossly inadequate to meet needs. From a human rights perspective, this is highly problematic for Afghan refugees who are not entitled to apply for any form of long-term protection status in Turkey as 'conditional protection' when granted is only temporary. The result of these systems are poor conditions for Afghans in Turkey. In this study respondents that had been in Turkey for the longer term used strategies such as co-owning a business with a local or someone who had another status in order to be able to work and make a decent living. However, the respondents stated always feeling vulnerable in this approach as they had no legal rights to the business.

Greece is a European country and thus a full signatory to the 1951 Geneva Convention, meaning that Afghans can apply for asylum status in Greece. Table 1 shows the number of Afghans that applied for asylum in Greece from 2008-2015. It is evident that compared to overall numbers of Afghan asylum claims in the EU in 2015, the number in Greece is relatively small. Previous research on Afghans in Greece has demonstrated that Afghans primarily view Greece as a transit country en route to their destination (Dimitriadi, 2015).

$<$ Table 1 Here>

Some Afghans do apply for protection status in Greece and if granted, children are permitted to go to school in Greece and adults are able to work. However, at the time of interview there was no support provided to asylum seekers or refugees by the government for accommodation, health care, or living expenses. In 2016 Greece adopted a new law that provides free health care to vulnerable people, including asylum seekers and refugees (AIDA, 2017). In light of the current economic crisis in Greece, it is understandable that services for refugees and asylum seekers are not able to be prioritized. It is 
challenging for any country to receive a mass influx of asylum seekers and this has only been exacerbated within the current conditions in Greece.

Both Greece and Turkey represent key countries of transit that Afghans need to pass through in order to reach their commonly targeted destination countries of Northern Europe. Although both Greece and Turkey are often perceived as transit countries they have very different geo-political positions. Turkey is the central departure point for Europe and a known transit country for most Afghan refugees prior to starting their journey. Greece is the primary entry point to Europe.

\section{Refugee Journeys and Afghans Decision Making in Greece and Turkey}

BenEzer and Zetter (2015) present four conceptual challenges to understanding refugee journeys. The first is the temporal aspect of the journey; when do journeys start? When do they end? How long does the journey last? In this paper, the temporal element of the journey is assessed as how long the refugee has been in the current country. This definition of time is chosen as it relates to the decision to stay or not in the current country and reflects on the duration and temporal elements of the journey. It is hypothesized that refugees who have been in the country of stay for longer durations of time will be more likely to choose to stay in the current country (H1).

The second aspect is the role of drivers and destinations in influencing refugee journeys (BenEzer and Zetter, 2015). Drivers are important as people flee for different reasons, which can have different impacts on their journeys. In this paper, the respondents did have different drivers triggering their exact moments into exile. The drivers of the refugee journeys are therefore included in the analysis. In terms of destinations BenEzer and Zetter (2015) question: 'Is the destination significant? What is the image of the destination in the minds of the wayfarers and how does this impact experiences and recollections of the journey?' (308). In this paper, destinations are included by examining if the current country was the intended destination of the refugee when they began on this journey. The beginning of the journey is considered here as the moment when they left the country they were last living in for a minimum of one year. I hypothesize that refugees that intended to migrate to the current country are more likely to seek to stay than migrate onwards ( $\mathrm{H} 2)$.

The third aspect highlighted by BenEzer and Zetter (2015) is the process of the journey;

'in other words, how does the journey unfold, what is its 'content', what are its major developments and constituents, what happens along the way, what are its unique characteristics?' (p.309) 
There are several elements that can be included in the process of the journey. In this paper, I examine five elements: 1) current subjective living conditions; 2) employment; 3) if the refugee experience abuse in the current country; 4) if the refugee has previously attempted to migrate onwards from the current country; and 5) the country of refuge (being Greece or Turkey). One other variable that was considered was if the refugee had migrated with a smuggler for any part of the journey. This was ultimately excluded from the analysis as 88 percent had migrated with a smuggler and the variation was too small.

A key driver for onwards migration is the perception of a better life in the destination country, which therefore reflects on the current subjective living conditions (de Haas, 2011). The third hypothesis is therefore Afghan refugees who rate their current subjective living conditions as good or very good will be less likely to seek to migrate onwards (H3).

Employment may act as a reason to stay by providing income and remittance capabilities (Collyer, 2006), or it may act as a driver for onwards migration in that the migrant is able to save for their onwards migration (Van Hear, 2006). Other research has demonstrated the importance of fulfilling the entire migration aspiration for Afghans (Donini et al., 2016), for which employment in transit may be a vital component in being able to achieve that aspiration. In this case, I hypothesize that Afghan respondents that are employed will be more likely to seek to migrate onwards ( $\mathrm{H} 4)$.

It is increasing recognized that poor conditions in transit countries, such as experiences of abuse and discrimination can be an impetus for onwards movement (Brewer and Yukseker, 2009). The fifth hypothesis is thus: Afghan refugees that have experienced verbal or physical abuse in the current country of transit will be more likely to seek to migrate onwards (H5).

A failed onwards migration attempt may deter an individual to seek to migrate onwards, or may be simply a part of their journey. Kaytaz (2016) found that in some cases a failed onwards migration attempt from Turkey led to Afghans choosing to stay in Turkey and apply for asylum. Other research suggests that a failed attempt will not deter achieving the overall migration ambition. In this case, I hypothesize that refugees that have tried to migrate onwards in the past are more likely to want to migrate onwards (H6).

The final variable examined in the process of the journey is to compare between the two countries of analysis of Greece and Turkey. A key challenge in Greece is that even if Afghans asylum claims are accepted there is little social protection available to refugees in Greece. The lack of assistance for refugees is a common reason for desiring to migrate onwards from Greece. In Turkey, the absence of an adequate protection regime for Afghans is a primary source for seeking to migrate onwards. Based 
on the above, I hypothesize that there will be no significant differences in Afghans decisions to migrate onwards or stay between Turkey and Greece (H7).

Finally, BenEzer and Zetter (2015) include as the forth aspect the characteristics of the wayfarers. In this paper the variables of ethnicity, current migration status, married, education level, and country of last resident prior to migration are all included in the analysis as control variables.

\section{Data and Methods}

This paper is based on a dataset of 364 questionnaires with Afghan refugees collected in Athens (166) and Istanbul (198) from May-July 2015. Due to the fact that the majority of Afghans in both of these countries may be irregular, simple random sampling was not possible. The sampling strategy was therefore based on first network and intercept point sampling on the street in communities where Afghan refugees were known to reside, and second, on snowball sampling from the respondents. A drawback to using snowball sampling is that respondents may be from within the same networks and not represent the diversity of Afghans situations in Athens and Istanbul, resulting in a skewed sample. The sample in this paper is clearly not representative of Afghans in Athens and Istanbul, but strong efforts have been to have multiple entry points for a diverse sample. The questionnaires were administered by Afghan refugees in each country trained by the research team. All of the fieldworkers selected had previously worked in research and/ or with refugees or other migrants. The in-depth training included information on recruitment, obtaining informed consent, and the principles of do no harm. The questionnaire was translated into Dari and Pashto and conducted using computer assisted personal interviewing (CAPI) methods on tablets. The benefits of the migrant to migrant interview approach included that the questionnaires were conducted directly in native languages without translation, refugees were able to travel inconspicuously to places of interest such as smugglers houses, and refugees were able to create trust for discussing sensitive information.

Follow-up in-depth interviews were also conducted with a small number of participants from the questionnaire $(n=15)$. Individuals were selected for interview based on the criteria of having a mix of employment and unemployment experiences, and a complex case that was identified by the interviewer as having multiple dimensions that were not necessarily all captured well within the questionnaire. These interviews have been used in this paper to assist in verifying and further contextualizing the results. 
Refugee decision making is conceptualized based on the question At this moment, do you want to: 1) stay in Greece/ Turkey, 2) migrate to another country; 3) return to your country of origin; 4) return to the country you were last living in. This question reflects the aspirations of the migrant at the moment, meaning that it is not reflecting their long-term plans, however, nor does the question require that the person currently has concrete plans in place for their onwards migration. Due to the low number of respondents that wanted to return to either their country of origin or country of last settlement $(n=11)$, I focus in this paper on the decision making between onwards migration and stay $(n=364)$.

The results are presented in two sections, the first as a descriptive overview and the second as the results of a regression analysis. As the purpose of this paper is to identify factors influencing the decision to migrate onwards, a standard probit model was estimated. The binary dependent variable takes the value of 1 if the migrant wants to migrate onwards and 0 if the migrant intends to stay in the country of transit. Denoting $y_{i}$ as the binary outcome variable, $\Phi$ as the standard normal distribution function, $\boldsymbol{x}_{\boldsymbol{i}}$ as the vector of explanatory variables, and $\boldsymbol{B}$ as the vector of coefficients to be estimated, the binary outcome model is given by:

$$
\operatorname{Pr}\left(y_{i}=1 \mid x_{i}\right)=\theta\left(x_{i} \beta\right) \text { with } \mathrm{i}=1, \ldots, \mathrm{N}
$$

In this case the dependent variable is the probability that an individual will migrate onwards. Prior to running the Probit regressions, pairwise correlation tests have been performed on the included variables as a first control for collinearity, as well as additional tabulations were done to control for a balanced distribution of the dummy variables. No variables were excluded from the initial model after the performed tests. The models are estimated with robust standard errors and results are presented as average marginal effects. The key independent variables of interest are: duration in the current country, main reason for current migration, if the current country was the original destination choice, subjective living conditions, experience of physical or verbal abuse, current employment, previous onwards migration attempt, and the current country of stay/transit. Control variables include: highest level of education completed, marriage, ethnicity, country of last residence, and current migration status. Appendix 1 provides an overview of all relevant variables used in the analysis. 


\section{Descriptive Statistics}

Table 2 shows the descriptive statistics of respondents based on their migration intention (whether they are planning to migrate onwards or stay). In both countries respondents indicate that they more often plan to migrate onwards, with a higher frequency in Greece (72.3\%) than in Turkey (58.6\%).

The descriptive statistics show some clear differences between the decisions to migrate onwards versus stay. In terms of the temporal element of the refugee journey, descriptively, respondents that had been in the current country for longer than three years were the most likely to plan to stay (59\%), followed by respondents who had been in the country for one to three years (35\%), with respondents who had been in the country for less than one year being the least frequently citing stay (17\%). It should be noted that a larger percentage of respondents had recently arrived in Turkey at 45 percent in the last three months as compared to Greece (25\%) and conversely that 44 percent of respondents in Greece had been there for more than three years compared to nine percent in Turkey.

There was little variation with regards to the drivers of migration and the decision to migrate onwards or stay, however, there was a significant difference with regards to destination choices. Only 27 percent of respondents that had migrated to Greece or Turkey as their intended destination from their country of last residence wanted to migrate onwards. It is important to note that the majority of respondents in the sample were not intending to migrate to Greece or Turkey (78\%). The main countries of destination choice amongst the respondents when they left their country of last residence included: Sweden (16\%), Canada (12\%), and Germany (10\%).

In terms of the process of the journey, five variables were examined. First, it is unsurprising that respondents who consider their current living situations as bad or very bad (represented as 0 in the dummy variable) are more likely to seek to migrate onwards (83\%) than respondents that consider their living conditions as average, good, or very good (represented as 1 in the dummy variable) (46\%). Second, respondents that were unemployed were more likely to seek to migrate onwards (76\%) than respondents who were employed (45\%). It is important to note that 82 percent of respondents that were working were employed informally. Third, respondents that had experienced verbal or physical abuse were more likely to seek to migrate onwards (67\%) than stay. Forth, respondents that had previously tried to migrate onwards unsuccessfully were more likely to want to migrate onwards (70\%).

Finally, a higher frequency of respondents in Greece (72\%) were planning to migrate onwards than in Turkey (59\%). A potential reason for this as suggested by Donini et al. (2016) is that once Afghans 
have made it to Greece they do not want to stop now that the hard part of the migration journey is over, and second, there is social pressure to reach the most preferred destinations.

$<$ Table 2 Here $>$

Turning to the control variables in the analysis there are also several differences in the descriptive statistics. Respondents that had been previously living in Afghanistan (69\%) are more likely to seek to migrate onwards than respondents that were last living in Iran (59\%), however the discrepancy is not that large. Hazaras (74\%) were the most likely to seek to migrate onwards, followed by Tajiks (60\%), other ethnic groups (52\%) and Pashtuns (50\%). Respondents that were married were more likely to seek to migrate onwards (68\%), and again there was little variation in terms of education levels and onwards migration (58-67\%).

In terms of current migration status, it is noteworthy that refugees and temporary protection holders are the most likely to seek to migrate onwards (78\%), however, this variable must be interpreted with caution. Only one respondent had refugee or temporary protection status in Turkey, compared to 90 respondents in Greece. Thus, 54 percent of the respondents currently in Greece are represented in the migration category refugees and temporary protection holders, compared to less than one percent of the respondents currently in Turkey. The high desire for onwards migration is followed by irregular refugees (68\%) and asylum seekers (53\%).

On the whole, the descriptive overview shows that respondents who consider themselves to be in poor living conditions, unemployed, have been in the country for a shorter duration of time, are currently residing in Greece, have refugee or temporary protection status and are from the Hazara ethnic group are more likely to seek to migrate onwards. The significance of this descriptive overview will be tested further in the regression analysis.

\section{Main Results}

This section discusses the results of the probit regression analysis, which are represented in Table 3 and shows how different factors correlate with the intention to migrate onwards.

$<$ Table 3 Here $>$

First, regarding the temporal element of the refugee journey respondents that had been in the country less than three years were significantly more likely to seek to migrate onwards as compared to those 
that had been in the current country for longer than three years. This ranged from 22 percentage points for a duration of stay of 4-11 months, to 32 percentage points for a duration of stay of 1-3 years. This confirms that temporal elements are significant in decision making within the refugee journey.

Second, the intended destination country was proven to be significant as respondents that had intended to migrate to Greece or Turkey and were currently in Greece or Turkey were 32 percentage points less likely to seek to migrate onwards. This highlights that the destination is significant in the journey and will be discussed further in the next section.

Third, regarding the process of the journey, current subjective living conditions were highly significant and the current country was somewhat significant. Respondents that rated their current subjective living conditions as good or very good are significantly less likely to seek to migrate onwards at 21 percentage points. Afghans in Greece were significantly more likely to seek to migrate onwards than from Turkey at 14 percentage points, but this was only slightly significant at the ten percent level. None of the other process of the journey variables were significant, suggesting that living conditions are the most important variable within the process of the journey.

Finally, control variables that were significant included current migration status and education levels. Current asylum seekers and other migrants were less likely to seek to migrate onwards as compared to those with an irregular status by 14 to 24 percentage points. Respondents with secondary education were ten percentage points more likely to seek to migrate onwards, but this was also only somewhat significant at the ten percent level. The results show that hypothesis statements $1,2,3$, and 7 can be accepted and statements 4-6 must be discarded.

\section{The Conceptual Challenges of the Refugee Journey and Decision Making for Onwards Migration}

The results illustrate that all four of the conceptual challenges of the refugee journey (BenEzer and Zetter, 2015) are significant in influencing the planned onwards migration decision of the Afghan respondents. First, the shorter the duration of time that an Afghan refugee had been in Greece or Turkey the more likely they are to plan to migrate onwards. This is logical as those who have been in the countries for a shorter period are more likely to plan to continue their migration aspiration to get to their intended destination. For respondents that have been in the country for longer periods of time there is a question as to if they choose to stay for settlement or feel 'stuck in transit'. A further look at descriptive statistics from the results suggests that both scenarios are present in the respondents in this study, but that a higher number of those stating they planned to stay were choosing to do so for positive 
reasons, such as settlement. Eighty percent of respondents in both countries choosing to stay stated that one of their decision making factors was 'it is a peaceful country', whereas only 15 percent in Greece and 4 percent of respondents in Turkey stated 'I do not want to stay'. This is a relatively positive finding suggesting that at the time of survey in 2015, Afghan refugees planning to stay in Greece or Turkey did not feel 'stuck in transit'. However, the same cannot necessarily be said for those planning to migrate onwards as the survey was cross-sectional and did not follow-up to see if their plans for onwards migration were realized or they became 'stuck in transit'. Furthermore, it is likely that the current situation in Turkey for Afghan refugees is quite different and is now more similar to the case of Indonesia where Afghans report feeling 'stuck in transit' (Missbach, 2015).

Second, destination choices proved to be an important element in decision making in the refugee journey. There is increasing research illustrating that refugees make informed decisions regarding their destination choices (Brekke and Aarset, 2009; Brekke and Brochman, 2015; Crawley et al., 2016; Koser and Pinkerton, 2002; Neumayer, 2004; Robinson and Segrott, 2002). This literature reflects the role of multiple aspects such as network connections, policies, and perceptions of the destination country that can influence refugees' selection of the destination choice. Further, Donini et al. (2016) have shown that neither Greece nor Turkey are viewed as desirable destinations for Afghans and that a successful migration is only seen as having reached Germany, the UK, or a Scandinavian country.

In this study, the majority of respondents had a clear target destination country in mind when they left their country of last residence and for the majority the target destination was not Greece or Turkey (78\%). For a very small percentage of respondents Greece was the intended destination (2\%) and this was much higher for Turkey at 20 percent. The three main reasons that respondents stated for choosing Turkey as their destination choice when leaving their country of last residence were: 'safe country' (89\%); 'employment opportunities' (84\%); and both 'family living in that country' and 'opportunities to make more money' (81\%). Afghan refugees that did intend to migrate to Greece or Turkey were significantly more likely to plan to stay in Greece or Turkey.

Third, the process of the refugee journey was conceptualized in this study through five factors of: 1) current subjective living conditions; 2) employment; 3) if the refugee experience abuse in the current country; 4 ) if the refugee has previously attempted to migrate onwards from the current country; and 5) the country of refugee (being Greece or Turkey). The results show that only the one factor of current subjective living conditions is significant in influencing the planned decision of the refugee journey. In Greece over half of respondents reported having bad or very bad living conditions (60\%) and in Turkey 
this number was lower at 41 percent. An increasing number of media articles have reported on dire living conditions for Afghan refugees in both Greece and Turkey, which is clearly an area of concern.

Fourth, the characteristics of the wayfarers has been examined. The only variable that was highly significant related to the current migration status of the Afghan refugee. Those with a pending asylum claim are more likely to seek to stay as compared to irregular migrants and respondents with refugee or temporary protection status. This was surprising in the case of respondents with refugee and temporary protection status (of which nearly all were in Greece) as by migrating beyond Greece they would lose the right to the protection status they have received. Two key reasons influencing this decision were first; for many Afghans, the status they had received in Greece was temporary and not permanent, meaning they had to re-apply every few years for status. This relates back to the temporal elements as having temporary status created uncertainty and anxiety for respondents. Second, despite having received protection many Afghan refugees lived in poor conditions in Greece and this prompted the desire to more onwards.

\section{Conclusion}

This paper has sought to understand decision making of Afghan refugees in their journeys to Europe by examining the factors that influence Afghan refugees' decision to stay or migrate onwards from Turkey and Greece. The aim is to contribute to the dearth of literature on refugee journeys and to illustrate how quantitative methods can also inform our understandings of refugee journeys. This paper follows the four conceptual challenges of the refugee journey identified by BenEzer and Zetter (2015) and assesses how these characteristics influence the planned decision of Afghan refugees. The findings demonstrate that duration in the current country, destination choices, living conditions, and migration status are all significantly correlated to the onward migration decision. These results contribute to understanding factors influencing onwards decision making in fragmented refugee journeys and clarifying influencing variables within these journeys.

It is important to note the limitations of the study approach in that the analysis is based on a cross-sectional survey that only allows for an individuals planned migration trajectory at one moment in time. It is possible, and highly likely, that these decisions change over time as refugees gain new access to information and respond to changing environments. Further, at the time of interview these are also only plans and it is beyond the scope of the survey methodology to know if they are actually realized. However, by still asking refugees of their plans for onwards migration or stay reflects their agency that can still be exercised despite the structural constraints to their mobility (Missbach, 2015). Second, quantitative surveys are not typically used to understand journeys and are limited in that they do not 
allow for an in-depth narrative account of the complexities of the journey and decision making within this journey. The benefit, however, is that a much larger number of respondents are accessible and that peer to peer research may allow for the respondent to be more comfortable in the research process.

Furthermore, the current context in Greece and Turkey is quite different than it was in 2015 at the time of this research. It is important to consider that if the same survey was replicated today (in 2017) the results would presumably look quite different with hypothetically a much higher number of respondents reflecting feelings of being stuck in transit. In 2015, onwards mobility was considered feasible and respondents discussed with the researcher when and how they were looking to go onwards, often with plans already in motion. Within these plans was a second key element of the refugee journey: hope. Many of the respondents still had hope which is a central factor influencing their journeys, and is arguably one that is difficult to assess in a survey, but that came through in the qualitative interviews conducted for this study. The hope of getting to the destination and the expectations for a better life in the destination were considered to be worth the risks and turbulence of the refugee journey.

Finally, the results of this study can inform policy, which is one of the identified goals of refugee journey research identified by BenEzer and Zetter (2015). First, the results demonstrate that destinations are important for several reasons; as a driver of the journey; as a reflection of the agency of the refugee; and as determinant of the end or continuation of a journey. Increasingly policy seeks to discount choice for asylum seekers, migrants and refugees in determining their destination and to instead, choose destinations for refugees by locking them in place, such as the EU-Turkey deal to prevent onwards migration, or even through constructive policies such as the EU relocation programme wherein refugees are not supposed to be able to choose their country of relocation. There is a need to find a better match between accounting for refugees' agency and destination choices and policies that seek to impose destinations on refugees as these destinations hold value and importance to the refugee. This should not be discounted as forcing refugees into undesirable destinations may fail to be a longterm solution.

Second, as has been prolifically highlighted by global media attention over the past two years conditions need to be improved for refugees in both Greece and Turkey. As evidenced by Leghtas and Sullivan (2017) Afghans in Turkey face multiple challenges of restricted movement, lack of access to livelihoods, health care, and education, and poor living conditions. In Greece, there are limited resources leaving refugees in temporary accommodations that are significantly overcrowded with poor conditions (IRC, 2017). Poor living conditions are a key driver for seeking to continue the journey and improving living conditions in these intended transit countries may influence decision making processes 
and enable refugees to choose to stay in Greece and Turkey versus compel their onwards migration. Improving living conditions is thus not only the humanitarian option for the dignity and human rights of the refugees, but also a key element in influencing the trajectories of their journeys.

Third, and perhaps the most alarming issue is the need for access to international protection. As stated at the beginning of this paper, I choose to use the label of 'refugee' for describing the Afghan respondents, recognizing the political constructs of terminology. Onwards migration from Turkey is most commonly viewed as 'economic migration' as evidenced by the EU Turkey Deal, but for Afghans there is no option for refuge and long-term international protection in Turkey. However, under the EU Turkey Deal Afghans should immediately be returned to Turkey upon arrival in Greece. Syrians are the only group eligible for resettlement from Turkey to Europe under the EU Turkey Deal, but there are other groups, including many Afghans, genuinely seeking protection and refuge that should be afforded the same rights. 


\section{References}

AIDA. (2017) Refugee rights subsiding? Europe's two-tier protection regime and its effect on the rights of beneficiaries. Brussels: European Council on Refugees and Exiles.

AIDA. (2017) Health Care Greece. Available at:

http://www.asylumineurope.org/reports/country/greece/reception-conditions/health-care Accessed on: 10 Nov 2017.

BENEZER, G. and ZETTER, R. (2015) 'Searching for Directions: Conceptual and Methodological Challenges in Researching Refugee Journeys' Journal of Refugee Studies 28(3): 297-318.

BREKKE, J.P. and AARSET, M.F. (2009) Why Norway: Understanding Asylum Destinations. Oslo: Institute for Social Research.

BREKKE, J.P. and BROCHMANN, G. (2015) 'Stuck in Transit: Secondary Migration of Asylum Seekers in Europe, National Differences, and the Dublin Regulation' Journal of Refugee Studies 28(2): 1-18.

BREWER, K. and YUKSEKER, D. (2009) A survey of African refugees and asylum seekers in Istanbul. In A. Icduygu, \& K. Kirisci, Land of Diverse Migrations. Istanbul Bilgi University Press: Istanbul.

COLLYER, M. (2006) States of insecurity: Consequences of Saharan transit migration. Oxford: Centre on Migration, Policy and Society, University of Oxford.

COLLYER, M. (2010) 'Stranded Migrants and the Fragmented Journey' Journal of Refugee Studies 23(3): 273-293.

COLLYER, M. and DE HAAS, H. (2012) 'Developing Dynamic Categorisations of Transit Migration'. Population, Space and Place 18: 468-481.

CRAWLEY, H., DUVELL, F., JONES, K., MCMAHON, S. and SIGONA, N. (2016) Destination Europe? Understanding the Dynamics and Drivers of Mediterranean Migration in 2015. MEDMIG Final Report. www.medmig.info/research-brief-destination-europe.pdf.

CRAWLEY, H. and SKLEPARIS, D. (2017) 'Refugees, migrants, neither, both: categorical fetishism and the politics of bounding in Europe's 'migration crisis". Journal of Ethnic and Migration Studies. Online First. DOI: 10.1080/1369183X.2017.1348224

DE HAAS, H. (2011) The determinants of international migration: Conceptualising policy, origin and destination effects. Oxford: DEMIG Project Paper 2.

DIMITRIADI, A. (2015) "Greece is like a door, you go through it to get to Europe." Understanding Afghan migration to Greece. Athens: IRMA Project Case Study.

DONINI, A., MONSUTTI, A., and SCALETTARIS, G. (2016) Afghans on the Move: Seeking Protection and Refgue in Europe. Geneva: Graduate Institute Geneva. 
EUROSTAT. (2016) Asylum and managed migration database. Available at: http://ec.europa.eu/eurostat/web/asylum-and-managed-migration/data/database Accessed on 26 August 2016.

FARZIN, F. and JADALI, S. 2013. "Freedom of Movement of Afghan Refugees in Iran." Forced Migration Review 44: 85-86.

ICDUYGU, A. (2015) Syrian Refugees in Turkey The Long Road Ahead. Washington, DC: Migration Policy Institute.

INELI CIGAR, M. (2015) 'Implications of the New Turkish Law on Foreigners and International Protection and Regulation no. 29153 on Temporary Protection for Syrians Seeking Protection in Turkey' Oxford Monitor of Forced Migration 4(2): 28-36.

JACOBSEN, K., AYOUB, M., and JOHNSON, A. (2014) 'Sudanese Refugees in Cairo: Remittances and Livelihoods Journal of Refugee Studies' 27(1): 145-159.

KAYTAZ, E. (2016) 'Afghan Journeys to Turkey: Narratives of Immobility, Travel and Transformation' Geopolitics 21(2): 284-302.

KILBERG, R. (2014) 'Turkeys Evolving Migration Identity.' Migration Information Source. Available at: http://www.migrationpolicy.org/article/turkeys-evolving-migration-identity

KOSER, K. and PINKERTON, C. (2002) The Social Networks of Asylum Seekers and the Dissemination of Information about Countries of Asylum. London: Home Office.

KUSCHMINDER, K. and SIEGEL, M. (2016) Rejected Afghan Asylum Seekers in the Netherlands: Migration experiences, current situations and future aspirations. UNU-Merit Working Paper, 2016-007.

MISSBAUCH, A. (2015) Troubled Transit: Asylum Seekers Stuck in Indonesia. Singapore: ISEAS.

NEYMAYER, E. (2004) 'Asylum destination choice: what makes some West European countries more attractive than others?' European Union Politics 5: 156-180.

LEGHTAS, I. and SULLIVAN, D. (2017) "Except God, We have no one": Lack of Durable Solutions for NonSyrian Refuges in Turkey. Washington: Refugees International

ROBINSON, V. and SEGROTT, J. (2002) Understanding the decision making of asylum seekers. London: Home Office Research, development and Statistics Directorate.

SCHAPENDONK, J. (2012) 'Migrants' im/mobilities on their way to the EU: Lost in transit?' Tijdschriftvoor Economischeen Sociale Geografie 112 : 577-583.

SCHUSTER, L. and MAJIDI, N. (2013) 'What Happens Post-Deportation? The Experience of Deported Afghans' Migration Studies 1(2): 221-40. 
TOWNSEND, J. and OOMEN, C. (2015) Before the Boat: Understanding the Migrant Journey. Brussels: Migration Policy Institute Europe.

UNHCR. (2010) Trees only move in the wind: A study of unaccompanied Afghan Children in Europe. Geneva: UNHCR.

UNHCR. (2017a) Syria Regional Refugee Response. Available at: http://data.unhcr.org/syrianrefugees/country.php?id=224 Accessed on: 2 Nov 2017.

UNHCR. (2017b) Resettlement Data. Available at: http://www.unhcr.org/resettlement-data.html Accessed on: 2 Nov 2017.

VAN HEAR, N. (2006) 'I went as far as my money would take me': conflict, forced migration and class. Oxford: COMPAS.

VERVLIET, M., VANOBBERGEN, B., BROEKART, E. and DERLUYN, I. (2014) 'The aspirations of Afghan unaccompanied refugee minors before departure and on arrival in the host country' Childhood: $1-16$.

ZETTER, R. (2007) 'More Labels, Fewer Refugees: Remaking the Refugee Label in an Era of Globalization' Journal of Refugee Studies 20(2): 172-192.

ZETTER, R. (2015) Protection in Crisis: Forced Migration and Protection in a Global Era. Washington, DC: Migration Policy Institute. 
Table 1: Afghan Asylum Applications and First Instance Decisions in Greece

\begin{tabular}{|lllllllll|}
\hline & $\mathbf{2 0 0 8}$ & $\mathbf{2 0 0 9}$ & $\mathbf{2 0 1 0}$ & $\mathbf{2 0 1 1}$ & $\mathbf{2 0 1 2}$ & $\mathbf{2 0 1 3}$ & $\mathbf{2 0 1 4}$ & $\mathbf{2 0 1 5}$ \\
\hline $\begin{array}{l}\text { Asylum } \\
\text { applications }\end{array}$ & 2285 & 1510 & 525 & 635 & 585 & 1225 & 1710 & 1725 \\
\hline $\begin{array}{l}\text { First } \\
\text { instance } \\
\text { Decisions }\end{array}$ & 2500 & 1600 & 205 & 320 & 370 & 930 & 1805 & 625 \\
\hline
\end{tabular}

Source: Eurostat, 2016. 'Asylum statistics'. Retrieved on: 14 March 2016. 
TABLE 2

DESCRIPTIVE RESULTS OF INDEPENDENT VARIABLES BY MIGRATION DECISION

\begin{tabular}{|c|c|c|c|}
\hline & $\begin{array}{c}\text { Onwards migration } \\
(\%)\end{array}$ & $\begin{array}{c}\text { Stay in Greece or } \\
\text { Turkey } \\
\text { (\%) }\end{array}$ & $\mathbf{N}$ \\
\hline \multicolumn{4}{|l|}{ Duration in transit } \\
\hline $0-3$ months & 82.8 & 17.2 & 122 \\
\hline 4-12 months & 64.1 & 35.9 & 78 \\
\hline $1-3$ years & 66.1 & 33.9 & 59 \\
\hline$>3$ years & 41.4 & 58.6 & 87 \\
\hline \multicolumn{4}{|l|}{ Main reason for recent migration } \\
\hline Security/political & 63.7 & 36.3 & 113 \\
\hline \multicolumn{4}{|l|}{$\begin{array}{l}\text { Risk of deportation/No right to education or } \\
\text { work/Police harassment/Did not have the }\end{array}$} \\
\hline right to stay in the country & 67.7 & 32.3 & 127 \\
\hline Lack of employment/educational & & & \\
\hline \multicolumn{4}{|l|}{ Family related reasons/Family formation/ } \\
\hline Other reasons/Poor access to health & 70.4 & 29.6 & 27 \\
\hline \multicolumn{3}{|l|}{ Current subjective living conditions } & 81 \\
\hline Bad or very bad & 83.2 & 16.9 & 184 \\
\hline Good, very good or average & 46.1 & 53.9 & 180 \\
\hline Experienced physical or verbal abuse & 67.2 & 32.9 & 137 \\
\hline \multicolumn{4}{|l|}{ Employment status } \\
\hline Currently employed (legal or illegal) & 44.7 & 55.3 & 132 \\
\hline Currently unemployed & 76.3 & 23.7 & 232 \\
\hline Has attempted to migrate onwards & 69.6 & 30.4 & 102 \\
\hline \multicolumn{4}{|l|}{ Transit migration country } \\
\hline Turkey & 58.6 & 41.4 & 198 \\
\hline Greece & 72.3 & 27.7 & 166 \\
\hline \multicolumn{4}{|l|}{ Country of residence prior to migration } \\
\hline Afghanistan & 58.8 & 41.2 & 131 \\
\hline Iran & 69 & 31 & 203 \\
\hline Other & 63.3 & 36.7 & 30 \\
\hline \multicolumn{4}{|l|}{ Ethnicity } \\
\hline Tajik & 59.5 & 40.5 & 121 \\
\hline Pashto & 50 & 50 & 40 \\
\hline Hazara & 73.8 & 26.2 & 172 \\
\hline Other & 51.9 & 48.2 & 27 \\
\hline \multicolumn{4}{|l|}{ Current migration status } \\
\hline Refugee/Temporary protection & 78 & 22 & 91 \\
\hline Asylum seeker & 52.7 & 47.3 & 74 \\
\hline Irregular & 67.7 & 32.3 & 167 \\
\hline Married & 68 & 32 & 100 \\
\hline \multicolumn{4}{|l|}{ Education levels } \\
\hline No formal education & 57.8 & 42.2 & 64 \\
\hline Primary education & 63.4 & 36.6 & 112 \\
\hline Secondary education & 68.6 & 31.4 & 121 \\
\hline $\begin{array}{l}\text { Higher education (Technical/Vocational } \\
\text { education/Bachelor) }\end{array}$ & 67.2 & 32.8 & 67 \\
\hline
\end{tabular}


TABLE 3

RESULTS PROBIT REGRESSION MIGRATION DECISION

\begin{tabular}{|c|c|}
\hline & $\begin{array}{c}\text { Transit migration decision - Migrate } \\
\text { onwards }\end{array}$ \\
\hline \multicolumn{2}{|l|}{ Duration in transit (Ref. category: $>3$ years) } \\
\hline $0-3$ months & $\begin{array}{c}0.28^{* * *} \\
(0.07)\end{array}$ \\
\hline 4-12 months & $\begin{array}{l}0.22^{* * *} \\
(0.06)\end{array}$ \\
\hline $1-3$ years & $\begin{array}{c}0.32^{* * *} \\
(0.6)\end{array}$ \\
\hline \multicolumn{2}{|l|}{ Main reason for recent migration (Ref. category: Security/political) } \\
\hline $\begin{array}{l}\text { Risk of deportation/No right to education or work/Police harassment/Did not have the right } \\
\text { to stay in the country }\end{array}$ & $\begin{array}{l}0.03 \\
(0.6)\end{array}$ \\
\hline Lack of employment/educational opportunities & $\begin{array}{l}-0.00 \\
(0.06)\end{array}$ \\
\hline Family related reasons/Family formation/ Other reasons/Poor access to health & $\begin{array}{l}-0.08 \\
(0.09)\end{array}$ \\
\hline Current Country is Intended Destination & $\begin{array}{l}-0.32^{* * *} \\
(0.05)\end{array}$ \\
\hline Current subjective living conditions - Good or average & $\begin{array}{c}-0.21^{* * *} \\
(0.04)\end{array}$ \\
\hline Experienced physical or verbal abuse & $\begin{array}{l}-0.01 \\
(0.05)\end{array}$ \\
\hline Employed & $\begin{array}{c}-0.05 \\
(0.05)\end{array}$ \\
\hline Has attempted to migrate onwards & $\begin{array}{c}-0.02 \\
(0.05)\end{array}$ \\
\hline Transit migration country - Greece & $\begin{array}{c}0.14^{*} \\
(0.07)\end{array}$ \\
\hline \multicolumn{2}{|l|}{ Country of residence prior to migration (Ref. category: Iran) } \\
\hline Afghanistan & $\begin{array}{l}-0.02 \\
(0.06)\end{array}$ \\
\hline Other & $\begin{array}{l}-0.05 \\
(0.08)\end{array}$ \\
\hline \multicolumn{2}{|l|}{ Ethnicity (Ref. category: Hazara) } \\
\hline Tajik & $\begin{array}{c}0.04 \\
(0.05)\end{array}$ \\
\hline Pashto & $\begin{array}{c}0.01 \\
(0.07)\end{array}$ \\
\hline Other & $\begin{array}{c}0.02 \\
(0.09)\end{array}$ \\
\hline \multicolumn{2}{|l|}{ Current migration status (Ref. category: Irregular) } \\
\hline Refugee/Temporary protection & $\begin{array}{l}-0.10 \\
(0.08)\end{array}$ \\
\hline Asylum seeker & $\begin{array}{c}-0.14^{* *} \\
(0.06)\end{array}$ \\
\hline Married & $\begin{array}{c}0.04 \\
(0.05)\end{array}$ \\
\hline \multicolumn{2}{|l|}{ Educational levels (Ref. category: No formal education) } \\
\hline Primary education & $\begin{array}{c}0.06 \\
(0.06)\end{array}$ \\
\hline Secondary education & $\begin{array}{c}0.10^{*} \\
(0.06)\end{array}$ \\
\hline Higher education (Technical/Vocational education/Bachelor) & $\begin{array}{c}0.08 \\
(0.07) \\
\end{array}$ \\
\hline $\begin{array}{l}\text { Pseudo R2 } \\
\text { N }\end{array}$ & $\begin{array}{l}0.37 \\
345\end{array}$ \\
\hline
\end{tabular}




\section{Appendix 1: DESCRIPTIVE RESULTS OF ALL RELEVANT VARIABLES}

\begin{tabular}{|c|c|c|c|c|c|}
\hline Variable name & $\begin{array}{c}\text { No. Of } \\
\text { observations }\end{array}$ & $\begin{array}{c}\text { Mean/ } \\
\text { Percentage }\end{array}$ & Standard Deviation & Min. & Max \\
\hline Dependent variables & & & & & \\
\hline $\begin{array}{l}\text { Migration decision - Migrate } \\
\text { onwards } \\
\text { Independent variables }\end{array}$ & 364 & .64 & .47 & 0 & 1 \\
\hline Duration in transit $-0-3$ months & 346 & .35 & .47 & 0 & 1 \\
\hline Duration in transit $-4-12$ months & 346 & .22 & .41 & 0 & 1 \\
\hline Duration in transit - $1-3$ years & 346 & .17 & .37 & 0 & 1 \\
\hline Duration in transit $->3$ years & 346 & .25 & .43 & 0 & 1 \\
\hline $\begin{array}{l}\text { Main reason for recent migration - } \\
\text { Security/political }\end{array}$ & 363 & .31 & .46 & 0 & 1 \\
\hline $\begin{array}{l}\text { Main reason for recent migration - } \\
\text { Risk of deportation/No right to } \\
\text { education or work/Police } \\
\text { harassment/Did not have the right to } \\
\text { stay in the country }\end{array}$ & 363 & .34 & .47 & 0 & 1 \\
\hline $\begin{array}{l}\text { Main reason for recent migration - } \\
\text { Lack of employment/educational } \\
\text { opportunities }\end{array}$ & 363 & .26 & .44 & 0 & 1 \\
\hline $\begin{array}{l}\text { Main reason for recent migration - } \\
\text { Family related reasons/Family } \\
\text { formation/Other reasons/Poor } \\
\text { access to health }\end{array}$ & 363 & .07 & .26 & 0 & 1 \\
\hline $\begin{array}{l}\text { Current country was intended } \\
\text { destination }\end{array}$ & 364 & .22 & .42 & 0 & 1 \\
\hline $\begin{array}{l}\text { Current subjective living conditions - } \\
\text { Good or average }\end{array}$ & 364 & .49 & .50 & 0 & 1 \\
\hline Experienced physical or verbal abuse & 364 & .37 & .48 & 0 & 1 \\
\hline Employed & 364 & .36 & .48 & 0 & 1 \\
\hline Has attempted to migrate onwards & 364 & .28 & .44 & 0 & 1 \\
\hline $\begin{array}{l}\text { Transit migration country - Greece } \\
\text { Control variables }\end{array}$ & 364 & .45 & .49 & 0 & 1 \\
\hline $\begin{array}{l}\text { Country of residence prior to } \\
\text { migration - Afghanistan }\end{array}$ & 364 & .35 & .48 & 0 & 1 \\
\hline $\begin{array}{l}\text { Country of residence prior to } \\
\text { migration - Iran }\end{array}$ & 364 & .55 & .49 & 0 & 1 \\
\hline $\begin{array}{l}\text { Country of residence prior to } \\
\text { migration - Other }\end{array}$ & 364 & .08 & .27 & 0 & 1 \\
\hline Ethnicity - Tajik & 364 & .33 & .47 & 0 & 1 \\
\hline Ethnicity - Pashto & 364 & .10 & .31 & 0 & 1 \\
\hline Ethnicity - Hazara & 364 & .47 & .49 & 0 & 1 \\
\hline Ethnicity - Other & 364 & .07 & .26 & 0 & 1 \\
\hline $\begin{array}{l}\text { Current migration status - } \\
\text { refugee/temporary protection }\end{array}$ & 364 & .25 & .43 & 0 & 1 \\
\hline $\begin{array}{l}\text { Current migration status - Asylum } \\
\text { seeker }\end{array}$ & 364 & .20 & .40 & 0 & 1 \\
\hline Current migration status - Irregular & 364 & .45 & .49 & 0 & 1 \\
\hline Current migration status - Other & 364 & .08 & .28 & 0 & 1 \\
\hline Married & 364 & .27 & .44 & 0 & 1 \\
\hline Level of education - None & 364 & .17 & .38 & 0 & 1 \\
\hline Level of education - Primary school & 364 & .30 & .46 & 0 & 1 \\
\hline $\begin{array}{l}\text { Level of education - Secondary } \\
\text { school }\end{array}$ & 364 & .33 & .47 & 0 & 1 \\
\hline $\begin{array}{l}\text { Level of education - Higher } \\
\text { education (Technical/Vocational }\end{array}$ & 364 & .18 & .38 & 0 & 1 \\
\hline
\end{tabular}


education/Bachelor) 